\title{
Front Matter: Volume 10614
}

, "Front Matter: Volume 10614," Proc. SPIE 10614, International Conference on Atomic and Molecular Pulsed Lasers XIII, 1061401 (9 May 2018); doi: $10.1117 / 12.2500231$

SPIE Event: XIII International Conference on Atomic and Molecular Pulsed Lasers, 2017, Tomsk, Russia 


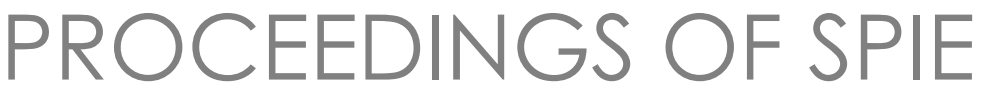

\title{
International Conference on Atomic and Molecular Pulsed Lasers XIII
}

\author{
Victor F. Tarasenko \\ Andrei M. Kabanov \\ Editors
}

10 - 15 September 2017 Tomsk, Russian Federation

Sponsored by

Russian Foundation for Basic Research (Russian Federation) - Siberian Branch of Russian Academy of Sciences (Russian Federation) - "TOPAZ" Research and Inculcation Enterprise (Russian Federation) • Crystaltechno Ltd. (Russian Federation) • SP Equipment (Russian Federation) • Intech Analytics Corporation (Russian Federation) • IC Specpostavka (Russian Federation) • CLZ Ltd. (Russian Federation)

Organized by

V.E. Zuev Institute of Atmospheric Optics SB RAS (Russian Federation) • Institute of High Current Electronics SB RAS (Russian Federation) - Institute of Monitoring of Climatic and Ecological System SB RAS (Russian Federation) • Tomsk State University (Russian Federation) • Tomsk Polytechnic University (Russian Federation) • P.N. Lebedev Physical Institute RAS (Russian Federation) - A.M. Prokhorov General Physics Institute RAS (Russian Federation) • Siberian Physical Technical Institute (Russian Federation)

Published by

SPIE

Volume 10614 
The papers in this volume were part of the technical conference cited on the cover and title page. Papers were selected and subject to review by the editors and conference program committee. Some conference presentations may not be available for publication. Additional papers and presentation recordings may be available online in the SPIE Digital Library at SPIEDigitalLibrary.org.

The papers reflect the work and thoughts of the authors and are published herein as submitted. The publisher is not responsible for the validity of the information or for any outcomes resulting from reliance thereon.

Please use the following format to cite material from these proceedings:

Author(s), "Title of Paper," in International Conference on Atomic and Molecular Pulsed Lasers XIII, edited by Victor F. Tarasenko, Andrei M. Kabanov, Proceedings of SPIE Vol. 10614 (SPIE, Bellingham, WA, 2018) Seven-digit Article CID Number.

ISSN: 0277-786X

ISSN: 1996-756X (electronic)

ISBN: 9781510617322

ISBN: 9781510617339 (electronic)

Published by

SPIE

P.O. Box 10, Bellingham, Washington $98227-0010$ USA

Telephone +1 3606763290 (Pacific Time) · Fax +1 3606471445

SPIE.org

Copyright (c) 2018, Society of Photo-Optical Instrumentation Engineers.

Copying of material in this book for internal or personal use, or for the internal or personal use of specific clients, beyond the fair use provisions granted by the U.S. Copyright Law is authorized by SPIE subject to payment of copying fees. The Transactional Reporting Service base fee for this volume is $\$ 18.00$ per article (or portion thereof), which should be paid directly to the Copyright Clearance Center (CCC), 222 Rosewood Drive, Danvers, MA 01923. Payment may also be made electronically through CCC Online at copyright.com. Other copying for republication, resale, advertising or promotion, or any form of systematic or multiple reproduction of any material in this book is prohibited except with permission in writing from the publisher. The CCC fee code is 0277 $786 \mathrm{X} / 18 / \$ 18.00$.

Printed in the United States of America.

Publication of record for individual papers is online in the SPIE Digital Library.

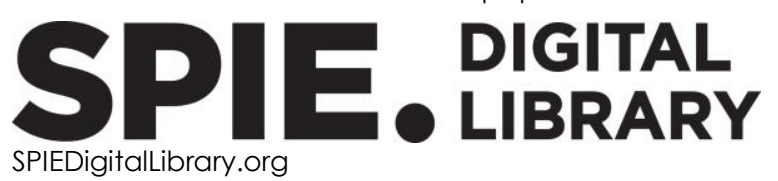

Paper Numbering: Proceedings of SPIE follow an e-First publication model. A unique citation identifier (CID) number is assigned to each article at the time of publication. Utilization of CIDs allows articles to be fully citable as soon as they are published online, and connects the same identifier to all online and print versions of the publication. SPIE uses a seven-digit CID article numbering system structured as follows:

- The first five digits correspond to the SPIE volume number.

- The last two digits indicate publication order within the volume using a Base 36 numbering system employing both numerals and letters. These two-number sets start with $00,01,02,03$, 04, 05, 06, 07, 08, 09, OA, OB ... 0Z, followed by 10-1Z, 20-2Z, etc. The CID Number appears on each page of the manuscript. 


\title{
Contents
}

\author{
ix Authors \\ xiii Conference Committee \\ xvii Introduction
}

ATOMIC AND MOLECULAR PULSED LASERS

1061402 Comparative analysis of parameters of pulsed copper vapour laser and known types of technological lasers [10614-33]

1061403 Amplification of spontaneous emission on sodium D-lines using nonresonance broadband optical pumping [10614-16]

1061404 Metal halides vapor lasers with inner reactor and small active volume [10614-22]

1061405 Characteristics of inductive coaxial copper vapour lasers [10614-87]

1061406 Stability of discharge in excimer gas media with high specific pump powers [10614-1]

1061407 A CuBr laser with high efficiency in the double-pumping-pulse mode [10614-27]

1061408 Changes in optical spectra of silver nanoparticles doped europium ions [10614-39]

1061409 Basic models of effective parameters for media with complex particles [10614-23]

10614 OA Study interaction between humic acids and metal ions using fluorescence quenching approach [10614-103]

$10614 \mathrm{OB}$ Optical methods for controlling the degree dehydrochlorination of polyvinylchloride [10614-37]

$106140 \mathrm{C}$ Effect of mint solution concentration on the absorption spectra of silver nanoparticles in thulium ions presence [10614-34]

10614 OD Features measurements of parameters weakly scattering nanoobjects [10614-24]

10614 OE Förster resonance energy transfer between quantum dots and dye immobilized in biopolymer particles [10614-60]

10614 OF Spectroscopy and photochemistry of humic acids [10614-26]

$106140 G$ Structure of post-filamentation zone by propagation of the femtosecond laser pulses [10614-10] 
$10614 \mathrm{OH} \quad$ Laser nanocomposites based on proteins and carbon nanotubes for restoration of biological tissues [10614-64]

10614 Ol The effect of the impurity-defective composition of a diamond sample on the optical absorption at a neutral vacancy [10614-90]

10614 OK Stimulated low-frequency Raman scattering in aqueous suspension of nanoparticles [10614-63]

$10614 \mathrm{OL}$ Development of the experimental setup for determination of nanoparticle sizes by nanotracking [10614-81]

$106140 \mathrm{OM}$ Effect of iron oxide nanoparticles on the concentration-versus-sizes relation of proteins in the blood plasma and serum, and in model solutions [10614-55]

$106140 \mathrm{~N}$ Anti-Stokes luminescence in nanoscale systems [10614-59]

1061400 The effect of tungsten on the properties of gold-doped silicon [10614-32]

10614 OP Laser cutting of sodium silicate glasses [10614-92]

$106140 Q \quad$ Mobile multiwave lidar [10614-109]

10614 OR A unit for registration of luminescence spectra of natural objects [10614-111]

10614 OS New stand for fluorescence study [10614-110]

10614 OU Upgrading of kilohertz solid-state laser system with stabilization CEO for nonlinear interaction of radiation with optical medium experiments [10614-67]

$106140 \mathrm{~V} \quad$ Numerical modeling of the vessel heating with copper vapor laser for treatment of vascular skin lesions [10614-86]

10614 OW Dissociation reactions of potassiated glucose: deionization, potassium hydroxide loss, and cross-ring dissociation [10614-88]

10614 OX Microstructure formation on liquid metal surface under pulsed action [10614-80]

10614 OY Identification of natural and synthetic diamonds by cathodoluminescence spectra [10614-35]

$106140 Z$ Non-linear optical properties of nanosized metal oxide particles obtained in plasma discharge in liquid phase under ultrasonic cavitation [10614-46]

1061410 Influence of approximation range of the hologram transmission spectrum on the inverse problem solution [10614-28]

1061411 Obtaining of hydrogen in acoustoplasma discharge in liquids [10614-49]

1061412 Study of physical properties of metal oxide nanoparticles obtained in acoustoplasma discharge [10614-50] 
1061413 Luminescent properties of nanoparticles synthesized in electric discharge in liquid under ultrasonic cavitation [10614-51]

1061414 Dynamic characteristics of electric discharge in liquid under ultrasonic cavitation [10614-52]

1061415 On one mechanism of light ablation of nanostructures [10614-100]

1061416 A mechanism for creating an inversion of populations of energy levels [10614-74]

1061417 Laser-induced dissociation processes of protonated glucose: dehydration reactions vs cross-ring dissociation [10614-76]

1061418 Simulation of the THz radiation in the tapered waveguide [10614-41]

1061419 The evolution of cryogenically cooled pump channel of high-intensity laser system with $1 \mathrm{kHz}$ repetition rate [10614-69]

$106141 \mathrm{~A}$ Photo- and electroluminescence of new organic semiconductors [10614-108]

10614 1B Peculiarities of light absorption by spherical microcapsules [10614-2]

$106141 \mathrm{C}$ Own waves in planar continuously heterogeneous structures with optical bianisotropy [10614-75]

10614 1D Features of laser air filamentation at aberration focusing [10614-21]

$106141 \mathrm{E}$ Use of UV radiation from a $\mathrm{KrCl}$ excilamp for the purpose of removing 2,4-D with $\mathrm{H}_{2} \mathrm{O}_{2}$ / Fenton additives [10614-42]

10614 IF Cathodoluminescent UV-radiation sources [10614-83]

$106141 G$ The application of UV LEDs for differential optical absorption spectroscopy [10614-54]

$106141 \mathrm{H} \quad$ Excitonic absorption and emission in diamond near the edge of fundamental absorption [10614-112]

$1061411 \quad$ NOx formation in apokamp-type atmospheric pressure plasma jets in air initiated by a pulse-repetitive discharge [10614-8]

$106141 \mathrm{~J} \quad$ Parametric study of dielectric barrier discharge excimer UV lamps supplied with controlled square current pulses [10614-107]

$106141 \mathrm{~K} \quad$ Reactor experiments to study luminescence of He-Ne and He-Kr gaseous mixtures, excited by the products of ${ }^{6} \mathrm{Li}(n, \boldsymbol{\alpha}){ }^{3} \mathrm{H}$ nuclear reaction [10614-82]

$106141 \mathrm{~L} \quad$ Ag nanoparticles suspensions for stimulated Rayleigh backscattering of single frequency 0.5 micron pulsed laser radiation [10614-38]

$106141 \mathrm{M}$ Investigation of temperature transition processes in optical-acoustic deflectors on the basis of paratellurit [10614-85] 
$106141 \mathrm{~N}$ Presowing $\mathrm{XeCl}$ excilamp irradiation of crops: field research and prospects [10614-7]

1061410 Threshold effect in properties of limiters for high-intensity laser radiation [10614-66]

$106141 \mathrm{P}$ Investigation of the electric field distribution in the human brain based on MRI and EEG data [10614-53]

$106141 Q \quad$ Improvement of the multiphoton fluorescence microscopy images quality using digital filtration [10614-98]

$106141 R \quad$ Visualization of nanoconstructions with DNA-Aptamers for targeted molecules binding on the surface of screen-printed electrodes [10614-101]

10614 is Mechanisms of the effect of VUV radiation on the microfungi [10614-77]

$106141 \mathrm{~T}$ Possibilities of cytospectrophotometry of oncological prostate cancer tissue analysis in the TGz spectral range [10614-94]

$106141 \mathrm{U}$ Marx generator on the basis of long lines for electron accelerators with beam extraction into gas [10614-62]

$106141 \mathrm{~V}$ Calculation of energy absorbed in the plasma of high voltage nanosecond discharge with subnanosecond rise-time of voltage impulse [10614-105]

10614 IW Ambipolar transport in the structure of gas discharge plasma [10614-56]

$106141 X \quad$ Runaway electron beams formed in atmospheric pressure air in a diode with dielectric films [10614-12]

$106141 Y$ The kernel construction for the biomedical data classification using support vector machine [10614-96]

1061412 THz laser spectroscopy exosome analysis of saliva and blood plasma [10614-95]

1061420 The study of the copper vapor brightness amplifier for long displacement objects visualization [10614-31]

$1061421 \quad$ Microstructure of copper surface treated by runaway electron preionized diffuse discharge in atmospheric pressure nitrogen stream [10614-89]

1061422 Kinetic model for $\mathrm{UV} / \mathrm{H}_{2} \mathrm{O}_{2}$ degradation of 8-methoxypsoralen [10614-15]

1061423 Spectroscopic behavior of pyrrolanthrone and its derivative in aprotic and protic solvents [10614-79]

1061424 SHG in Y-Ga $\mathbf{S}_{3}$ powder [10614-84]

1061425 All-fiber mode-locked erbium-doped ring laser based on a highly-nonlinear resonator with a low-noise ultrashort pulse generation [10614-68]

1061426 Dependence of fluorescent ability on efficiency of intersystem conversion in 8-methoxypsoralen and khellin [10614-73] 
1061427 Development of the control system for bistatic laser monitor [10614-30]

1061428 Investigation of compression conditions of subnanosecond pulse in the visible spectral range [10614-6]

1061429 Experimental study of the characteristics of the propagation of femtosecond radiation: results of the dispersion spreading [10614-104]

$106142 \mathrm{~A}$ Photonics of boron fluoride and zinc dipyrromethene complexes [10614-106]

$106142 B$ Use of absorption spectra and their second-order derivative to quantify degradation of lignohumate by filamentous fungi [10614-93]

$106142 \mathrm{C}$ Effect of iron oxide nanoparticles on the blood coagulation according to light scattering data [10614-72]

10614 2D Copper bromide vapor active medium ASE mode at high PRFs [10614-45]

$106142 \mathrm{E}$ Parametric amplifiers with multiple beams pumping for high-power laser systems of the femtosecond range [10614-91] 
Proc. of SPIE Vol. 10614 1061401-8

Downloaded From: https://www.spiedigitallibrary.org/conference-proceedings-of-spie on 26 Apr 2023 Terms of Use: https://www.spiedigitallibrary.org/terms-of-use 


\section{Authors}

Numbers in the index correspond to the last two digits of the seven-digit citation identifier (CID) article numbering system used in Proceedings of SPIE. The first five digits reflect the volume number. Base 36 numbering is employed for the last two digits and indicates the order of articles within the volume. Numbers start with 00, 01, 02, 03, 04, 05, 06, 07, 08, 09, OA, OB...0Z, followed by 10-1Z, 20-2Z, etc.

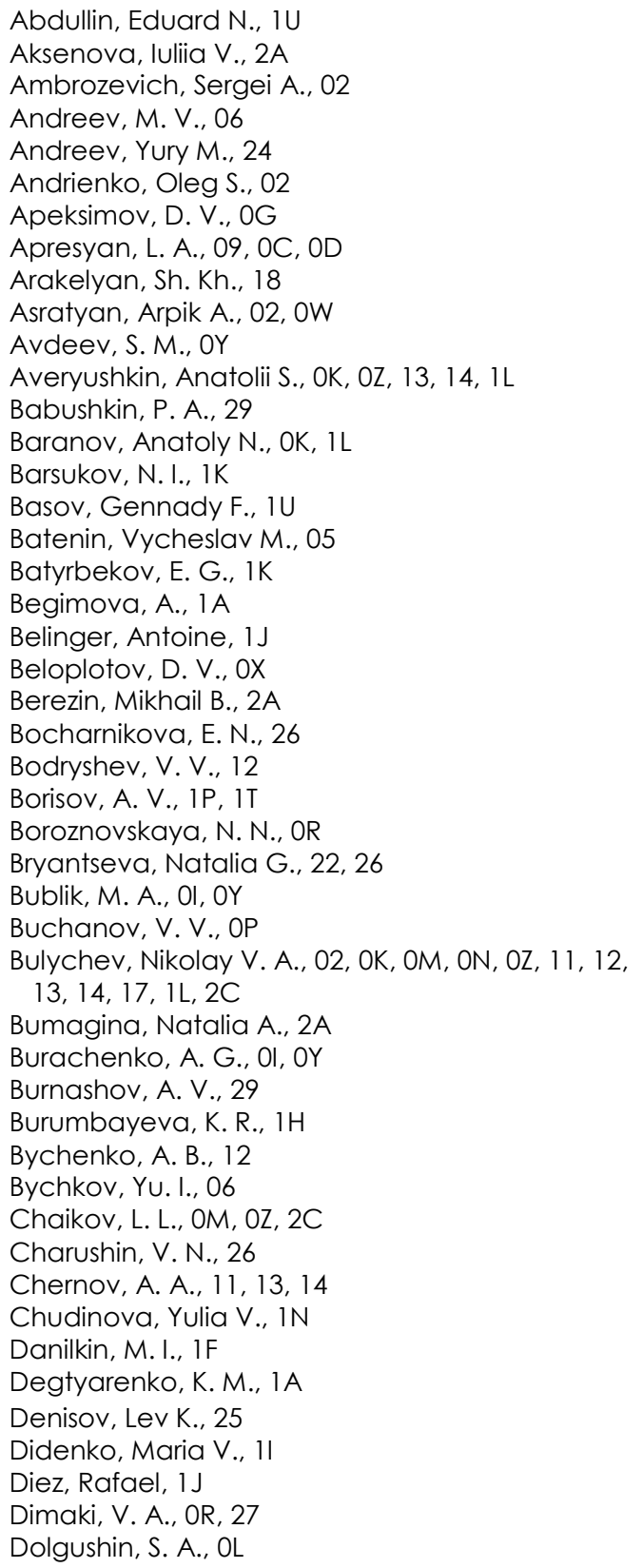

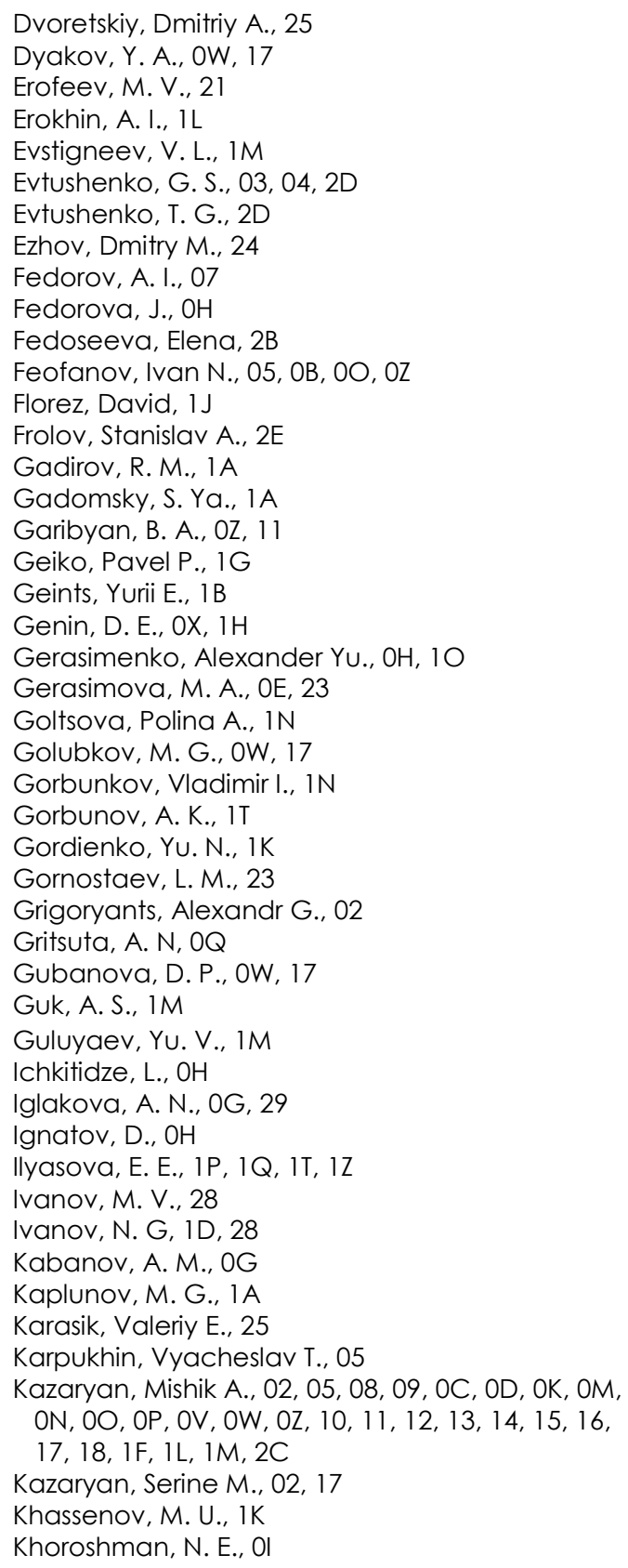


Khundzhua, Daria, 2B

Kireeva, Anastassiya I., 1C

Kirichenko, M. N., OM, 11, 12, 13, 14, 2C

Kirpichnikov, A. V., OU, 19

Kirtsideli, Irina, is

Kistenev, YU. V., 1P, 1Q, IT

Klimkin, Anton V., OQ, OR, OS

Klyuchareva, Svetlana V., OV

Knyazkova, A. I., 1P, 1T, 12

Kokh, Konstantin A., 24

Kokhanenko, Grigorii P., OQ, OS

Kokovin, A. O., $1 \mathrm{~V}$

Kolovskaya, Olga S., IR

Kononov, M. A., 00

Konovalov, I. N., 06

Kopylova, T. N., 1A

Korneva, A. P., OR

Kostyrya, Igor D., IX

Kraiski, Aleksandr V., 10

Kraiski, Anton A., 10

Krasnikova, S. S., 1 A

Krasovskiy, V. I., 08, 09, 0B, OC, OD, 00, 0Z

Krayukhina, Vlada, 22

Kryshtob, V. I., 08, 09, OB, OC, OD

Kuchinskaya, O. I., OG

Kudelin, Igor S., 25

Kudryavtseva, Anna D., OK, ON

Kulsartov, T. V., $1 \mathrm{~K}$

Kuptsov, G. V., OU, 19

Kurilova, Ulyana E., OH, 10

Kuryak, Alexey N., OQ, OS

Kustov, M. E., OP

Kuznetsov, Artem B., 24

Kuznetsova, Mariya $\vee$., ON

Kuznetsova, Rimma T., 2A

Kvasnov, B. A., OL

Lanskii, Gregory V., 24

Lapin, Ivan N., IR

Laptev, A. V., OU, 19

Lepnev, L. S., 13

Lidskii, Vladimir. V., 15

Limonova, Tatyana F., ON

Linkevich, Elizaveta $\vee ., O A$

Lipatov, E. I., Ol, OY, $1 \mathrm{H}$

Liu, Dongping P., 11

Lomaev, M. I., IV

Losev, V. F., 06, 1D, 28

Lubenko, D. M., ID

Lushnevskii, D. I., 2D

Lyabin, Nikolay A., 02, 05

Machs, Eduard, is

Malikov, Mikhail M., 05

Masalov, A. V., OM, 2C

Mashir, Yu. I., OP

Matvienko, G. G., OG

Mayer, Georgy V., OF, 2A

Medvedev, A. E., IW

Merezhko, A. G., 23

Mironova, Tatiana $V_{\text {., }} 10$

Mkhitaryan, Razmik G., 02
Mokrushin, Yu. M., IM

Morozova, E. A., 11, 1M

Murav'ev, E. N., OP

Musorov, I. S., 2D

Nechaev, L. V., OA

Nikoghosyan, A. S., 18

Nikolaev, V. V., 1Q, 1 Y

Novikov, I. K., 08, OB, OC

Odintsova, E. S., OL

Odod, A. V., IA

Orekhov, llya O., 25

Oshlakov, V. K., OG, 29

Osipov, Konstantin YU., OQ, OS

Ozol, D. I., IF

Panarin, Victor A., 11, 1N

Panchenko, A. N., OX

Panchenko, Yu. N., 06

Panina, Ekaterina K., 1B

Patsaeva, Svetlana, 2B

Pechenitsin, Dmitriy S., $1 \mathrm{~N}$

Pestryakov, E. V., OU, 19

Petrov, A. V., OG

Petrov, V. A., OU, 19

Petrov, V. V., OU, 19

Petukhov, T. D., 03

Piquet, Hubert, $1 \mathrm{~J}$

Pnev, Alexey B., 25

Poberezhnikov, A. D., 16

Podgaetsky, Vitaly M., $\mathrm{OH}, 10$

Polokhin, A., $\mathrm{OH}$

Ponkratov, YU. V., IK

Ponomarev, Igor $V_{\text {., }} \mathrm{OV}$

Ponomarev, YU. N., OQ

Postnikov, Vladimir A., 10

Privalova, P., $\mathrm{OH}$

Prokopenko, Alexander A., 2A

Prokop'ev, V. E., OR, ID

Puchikin, A. V., 06

Pushkareva, Aleksandra E., OV

Rasmagin, S. I., 08, 09, OB, OC, OD, 00, OZ

Revenko, V.I., OP

Ripenko, Vasilii S., 1H, 1V, 21

Rudenok, Igor P., IC

Ryabkin, D., $\mathrm{OH}$

Sachkov, Victor I., 02, 05, 15, 16

Samarkhanov, K. K., $1 \mathrm{~K}$

Samokhvalov, Ignatii V., IG

Samsonova, L. G., 1 A

Sandykova, E. A., 1P, 1Q, 1T, 1Y, 12

Savelyev, Mikhail S., $\mathrm{OH}, 10$

Savelyeva, Anna $\mathrm{V}$., OA

Sazonkin, Stanislav G., 25

Selishchev, Sergey V., 10

Shabalina, Anastasiia V., $1 R$

Shakin, O. V., $1 \mathrm{M}$

Shalaev, P. V., OL

Shamanin, I. V., 16

Shamanin, V. I., 16

Shapovalov, A. V., IP, IY

Shershnev, Sergey, $1 \mathrm{U}$ 
Sheshin, E. P., 1F

Shevchenko, Mikhail A., OK, ON, 10

Shevchenko, S. N., 12

Shiganov, Igor N., 02

Shiyanov, D. V., 04, 07, 2D

Shulepov, M. A., 1H, 21

Shuo, Zhang, OS

Simonova, G. V., $O Q$

Skakun, Victor S., 11, $1 \mathrm{~N}$

Skobczova, K. A., OF

Slyusarenko, N. V., OE

Slyusareva, E. A., OE, 23

Smirnov, Sergey S., $1 G$

Sokolova, I. V., OF, 1E

Sokovikov, Vladimir G., OR, OS

Solinov, E. F., OP

Song, Ying, 11

Sosnin, Eduard A., 11, 1N

Spassky, D. A., $1 \mathrm{~F}$

Spirina, L. V., IT

Stakheeva, M. N., 12

Strokov, Maxim A., OK

Sukhanov, V. B., 04

Sultanov, Takhir T., 10

Svetlichnyi, Valery A., 1R, 24

Talalaev, M. A., $1 \mathrm{M}$

Tanichev, Alexander S., 24

Tarasenko, Victor F., OI, OX, OY, 1H, 1I, 1N, 1X, 21

Tchaikovskaya, Olga N., OA, OF, 22, 26

Tcherniega, Nikolay V., OK, ON

Tel'minov, E. N., 03

Terekhova, Vera, 2B

Tereshchenko, Sergey A., OL, 10

Timoshenko, V. Yu., 12

Tonoyan, Garnik A., 02

Torgaev, S. N., 2D

Trigub, M. V., 20, 27

Tropina, D. A., 23

Trunov, Vladimir I., OU, 2E

Tugutova, E. A., $1 Z$

Tulubayev, Ye. Yu., $1 \mathrm{~K}$

Vangonen, Albert, $1 S$

Vasnev, N. A., 20, 27

Vereschagina, N. YU., $1 F$

Vershinin, N. O., OF, $1 \mathrm{E}$

Viktorova, Irina A., $1 \mathrm{~N}$

Vlasov, V. V., 20, 27

Voronkova, Natalia A., $1 \mathrm{~N}$

Vrazhnov, D. A., 1Y

Wiesner, Arnold, $1 \mathrm{~J}$

Yakunin, V. G., 12

Yakuschenko, I. K., $1 \mathrm{~A}$

Yampolskaya, S. A., 06

Yudina, Nataly $\vee ., 0 A$

Yunusova, N. V., $1 Z$

Zadorin, D. A., $\mathrm{OZ}$

Zakharyan, A. R., 0Z, 12, 13, 14

Zasedatel, V.S., 1 Z

Zaurbekova, Zh. A., 1K

Zemlyanov, Alexander A., 0G, IB
Zemskov, Konstantin I., OK, ON

Zhurbina, $\mathrm{N}$., $\mathrm{OH}$

Zuev, V. V., 00

Zvereva, Galina, 1S 
Proc. of SPIE Vol. 10614 1061401-12 Downloaded From: https://www.spiedigitallibrary.org/conference-proceedings-of-spie on 26 Apr 2023
Terms of Use: https://www.spiedigitallibrary.org/terms-of-use 


\title{
Conference Committee
}

\author{
Conference Chairs
}

Victor F. Tarasenko, Institute of High Current Electronics, Siberian Branch of the RAS (Russian Federation)

Andrei M. Kabanov, V.E. Zuev Institute of Atmospheric Optics of the Siberian Branch of the RAS (Russian Federation)

International Organizing Committee

Gennadii G. Matvienko, (Chair) V.E. Zuev Institute of Atmospheric Optics of the Siberian Branch of the RAS (Russian Federation)

Gennadiy S. Evtushenko, (Co-Chair) National Research Tomsk Polytechnic University (Russian Federation) V.E. Zuev Institute of Atmospheric Optics of the Siberian Branch of the RAS (Russian Federation)

Anton V. Klimkin, (Scientific Secretary) V.E. Zuev Institute of Atmospheric Optics of the Siberian Branch of the RAS (Russian Federation)

Mikhail V. Erofeev, (Secretary) National Research Tomsk Polytechnic University (Russian Federation) Institute of High Current Electronics, Siberian Branch of the RAS (Russian Federation)

Yuri S. Akishev, Troitsk Institute for Innovation and Fusion Research (Russian Federation)

Kerim R. Allakhverdiev, Materials Institute (Turkey), National Aviation Academy (Azerbaijan)

Yury Andreev, Institute of Monitoring of Climatic and Ecological Systems of Siberian Branch of the RAS (Russian Federation)

Gleb Baryshnikov, National University of Cherkasy (Ukraine)

Pyotor A. Bokhan, Institute of Semiconductor Physics of Siberian Branch of the RAS (Russian Federation)

Vladimir Burtman, University of Utah (United States)

Gennady Chebotarev, Southern Federal University (Russian Federation)

Gary J. Eden, University of Illinois (United States)

Konstantin Nikolaevich Firsov, National Research Nuclear University (Russian Federation)

Zhiming Huang, Shanghai Institute of Technical Physics (China)

Andrey A. Ionin, P.N. Lebedev Physical Institute of the RAS (Russian Federation)

Mishik Kazaryan, P.N. Lebedev Physical Institute of the RAS (Russian Federation) 
Tatyana Nikolaevna Kopylova, Siberian Physical Technical Institute

(Russian Federation)

Ivan B. Kovsh, Laser Association (Russian Federation)

Vitaliy Krasovskiy, A.M. Prokhorov General Physics Institute of the RAS

(Russian Federation)

Bernard Lacour, Université Paris-Sud (France)

Evgueniy L. Latush, Southern Federal University (Russian Federation)

Valery F. Losev, Institute of High Current Electronics of Siberian Branch of the RAS (Russian Federation)

Georgy Mayer, Tomsk State University (Russian Federation)

Boris Minaev, National University of Cherkasy (Ukraine)

John Molloy, National Physical Laboratory (United Kingdom)

Vladimir Osipov, Institute of Electrophysics of the RAS (Russian Federation)

Hubert Piquet, Université Toulouse (France)

Alexander Michailovich Razhev, Institute of Laser Physics of Siberian Branch of the RAS (Russian Federation), Novosibirsk State Technology University (Russian Federation)

Kenneth Ruud, The Arctic University of Norway (Norway)

Nicola V. Sabotinov, Institute of Solid State Physics (Bulgaria)

Anatoliy N. Soldatov, Tomsk State University (Russian Federation)

Ivan Sapssovsky, Frascati Research Center ENEA (Italy)

Fedor Alekseevich Starikov, The All-Russian Research Institute of Experimental Physics (Russian Federation)

Victor Tarasenko, Institute of High Current Electronics of Siberian Branch of RAS (Russian Federation)

Milan S. Trtica, Institute of Nuclear Sciences (Serbia)

Andreas Ulrich, Technische Universität München (Germany)

Aleksey Yakovlev, Tomsk Polytechnic University (Russian Federation)

A. A. Zemlyanov, V.E. Zuev Institute of Atmospheric Optics of Siberian Branch of the RAS (Russian Federation)

\section{Session Chairs}

A Gas and Plasma Lasers, Metal Vapor Lasers

Anna V. Vasilieva, Tomsk State University (Russian Federation)

Nikolay A. Yudin, Tomsk State University (Russian Federation)

B Photonics of Optical Materials, Optoelectronics

Ruslan M. Gadirov, Tomsk State University (Russian Federation)

T. Kopylova, Siberian Physical Technical Institute (Russian Federation)

C Femtosecond Laser Systems

L. Mikheev, P.N. Lebedev Physical Institute of the RAS (Russian Federation)

Andrey Buligin, V.E. Zuev Institute of Atmospheric Optics of Siberian Branch of RAS (Russian Federation) 
Laser Systems and New Laser and Optical Technologies, Laser

Applications

G. Evtushenko, Tomsk Polytechnic University (Russian Federation)

Kazaryan Mishik, P.N. Lebedev Physical Institute of the RAS

(Russian Federation)

Stanislav N. Torgaev, Tomsk Polytechnic University

(Russian Federation)

E Non-coherent UV and VUV-Radiation Sources

E. Sosnin, Institute of High Current Electronics of Siberian Branch of RAS (Russian Federation)

Evgeniy I. Lipatov, Institute of High Current Electronics of Siberian Branch of RAS (Russian Federation)

F Conversion of Laser Radiation, Optoelectronic Devices, Nonlinear Optics

John Molloy, National Physical Laboratory (United Kingdom)

V. Svetlichnyi, Siberian Physical Technical Institute (Russian Federation)

G Biophotonics

Yu. Kistenev, Tomsk State University (Russian Federation)

Galina Zvereva, S.I. Vavilov State Optical Institute (Russian Federation)

H Gas Discharges for Lasers and Non-coherent Radiation Sources

V. F. Tarasenko, Institute of High Current Electronics of Siberian Branch of RAS (Russian Federation)

Mikhail V. Erofeev, Institute of High Current Electronics of Siberian Branch of RAS (Russian Federation), National Research Tomsk Polytechnic University (Russian Federation)

George Naidis, High Temperature Institute of RAS

(Russian Federation)

Y AMPL School

Jochen Wieser, OPTIMARE Analytik GmbH \& Co. KG (Germany)

Kerim R. Allakhverdie, Materials Institute (Turkey), National Aviation Academy (Azerbaijan)

Anton V. Klimkin, V.E. Zuev Institute of Atmospheric Optics of Siberian Branch of RAS (Russian Federation) 
Proc. of SPIE Vol. 10614 1061401-16 Downloaded From: https://www.spiedigitallibrary.org/conference-proceedings-of-spie on 26 Apr 2023
Terms of Use: https://www.spiedigitallibrary.org/terms-of-use 


\section{Introduction}

The conference organizers of the Thirteenth International Conference on Atomic and Molecular Pulsed Lasers (AMPL) included: the Institute of Atmospheric Optics Siberian Branch of the RAS (Russian Federation), the Institute of High Current Electronics Siberian Branch of the RAS (Russian Federation), the Institute of Monitoring of Climatic and Ecological System of the RAS (Russian Federation), Tomsk State University (Russian Federation), Tomsk Polytechnic University (Russian Federation), the Siberian Physical Technical Institute (Russian Institute), P.N. Lebedev Physics Institute RAS (Russian Federation), and the A.M. Prokhorov General Physics Institute RAS (Russian Federation).

AMPL has traditionally been devoted to subjects such as physical processes in laser active media, new active media and pumping methods, new lasers development technologies, fundamental issues of laser physics, and non-coherent UV and VUVradiation sources. One of the principal goals of the conference has been contiguity of fundamental and applied sciences. Therefore, much attention was paid to the application of lasers and excilamps in science, engineering, medicine, and other areas of activity, as well as to discussion of problems of laser and excilamp-based apparatus and new optical technologies.

The scientific program of the conference included papers from the following sessions:

Session A: Gas and Plasma Lasers, Metal Vapor Lasers;

Session B: Photonics of Optical Materials, Optoelectronics;

Session C: Femtosecond Laser Systems;

Session D: Laser Systems and New Laser and Optical Technologies, Laser Applications;

Session E : Non-coherent UV and VUV-Radiation Sources;

Session F: Conversion of Laser Radiation, Optoelectronic Devices, Nonlinear Optics

We wish to thank our sponsors for their contributions to the success of the symposium: Russian Foundation for Basic Research (Russian Federation), Siberian Branch of Russian Academy of Sciences (Russian Federation), "TOPAZ" Research and Inculcation Enterprise (Russian Federation), Crystaltechno Ltd., Moscow (Russian Federation), SP Equipment, Novosibirsk (Russian Federation), Intech Analytics Corporation, St. Petersburg (Russian Federation), IC Specpostavka, SaintPetersburg (Russian Federation), and CLZ Ltd, Moscow (Russian Federation).

The International Conference on Atomic and Molecular Pulsed Lasers was first held in Tomsk (Russian Federation) in 1992; and in 1995 it became a biennial scientific forum hosted in Tomsk (Russian Federation). 
The AMPL agenda has covered the following issues: physical processes in gas lasers, including excimer lasers, metal vapor lasers, and plasma lasers; dye lasers and photoprocesses in complex organic molecules, photonics of optical materials; incoherent UV and VUV sources; diffuse discharges initiated by runaway electrons; conversion of laser radiation; optoelectronic devices; laser systems and advanced laser optics technologies; applications of lasers in different fields of science and technology, including ecology, medicine, industry, scientific research, struggle against terrorism; creation of laser-based devices. The AMPL program has also covered related issues such as research in non-laser pulsed UV sources, nonconventional isotope separation methods, optoacoustic devices, etc. Since 2009 it has included problems of femtosecond laser systems. The conference has also provided special sessions. In particular, a special session devoted to diffuse discharges initiated by runaway electrons was organized two times: in 2011 and 2013.

Generally, about two hundred reports (of which half tend to be oral) get presented at the conference. The AMPL conference has gained wide acceptance in the scientific community involved with laser research, attracting scientists from different countries and cities of the Russian Federation, which would be impossible without close cooperation of Tomsk scientific and educational institutions. Students from Tomsk State University (Russian Federation) and Tomsk Polytechnic University (Russian Federation) have attended each conference. An AMPL School Conference of young scientists has been held as part of each AMPL conference. During the conference, excursions were made to scientific laboratories of Tomsk institutes and universities.

The conference was held twelve times and all twelve times the Chair of its Organizing Committee was Professor Victor F. Tarasenko from the Institute of High Current Electronics, Siberian Branch of the RAS (Russian Federation). The conference materials have been published and can be found in issues of Atmospheric and Ocean Optics (Optika Atmospfery i Okeana), collections of the International Society for Optics and Photonics (1995- V.2619; 1997- V.3403; 1999V.4071; 2001- V.4747; 2003- V.5483; 2005- V.6263; and 2008- V. 6938), Quantum Electronics (Kvantovaya Elektronika), and the Bulletin of the Tomsk Polytechnic University (Izvestia TPU).

The next AMPL conference in Tomsk will take place in September 2019.

Victor F. Tarasenko Andrey M. Kavanov 